\title{
РОБОЧЕ МІСЦЕ ЛІКАРЯ-ПЕДІАТРА
}

\author{
В. 3. Стецюк, Т. П. Іванова ${ }^{1}$, І. П. Муха, \\ Л. Ю. Бабінцева², Н. В. Ольхович, Ю. М. Чиж \\ Національний технічний університет України \\ «Київський політехнічний інститут імені Ігоря Сікорського» \\ ${ }^{1}$ Національна дитяча спеціалізована лікарня «ОХМАТДИТ» \\ ${ }^{2}$ Національна медична академія післядипломної освіти імені П. Л. Шупика
}

\begin{abstract}
У статті описаной комп'ютерний програмний комплекс автоматизованого ведення первинної облікової медичної документації «Медичний реєстратор», розроблений для оптимізації роботи лікаря-педіатра та медичної сестри педіатричної дільниці, яка веде облік документації.
\end{abstract}

Ключові слова: дитяча смертність, первинна облікова медична документація, статистична звітність, база даних, педіатрична дільниця, програмний комплекс, медичні картки.

\section{WORKPLACE OF A PEDIATRICIAN}

\author{
V. Z. Stetsyuk, T. P. Ivanova ${ }^{1}$, I. P. Muha, \\ L. Yu. Babintseva², N. V. Olhovych, Yu. M. Chyzh \\ National Technical University of Ukraine «Igor Sikorsky Kyiv Polytechnic Institute» \\ ${ }^{1}$ National Children's Hospital «OKHMATDYT» \\ ${ }^{2}$ Shupyk National Medical Academy of Postgraduate Education
}

The article describes the computer software complex of automated maintenance of the primary medical accounting documentation «Medical Registrar», which was developed to optimize the work of a pediatrician and pediatric nurse, who keeps accounting documentation.

Key words: infant mortality, primary accounting medical documentation, statistical reporting, database, pediatric district, program complex, medical cards.

\section{РАБОЧЕЕ МЕСТО ВРАЧА-ПЕДИАТРА}

\author{
В. 3. Стецюк, Т. П. Иванова ${ }^{1}$, И. П. Муха, \\ Л. Ю. Бабинцева², Н. В.Ольхович, Ю. М. Чиж \\ Национальный технический университет Украины \\ «Киевский политехнический институт имени Игоря Сикорского» \\ ${ }^{1}$ Национальная детская специализированная больница «ОХМАТДЕТ» \\ ${ }^{2}$ Национальная медицинская академия последипломного образования \\ имени П. Л. Шупика
}

В статье описан компьютерный программный комплекс автоматизированного ведения первичной учетной медицинской документации «Медицинский регистратор», разработанный для оптимизации работы врача-педиатра и медицинской сестры педиатрического участка, ведущей учет документации.

\footnotetext{
Ключевые слова: детская смертность, первичная учетная медицинская документация, статистическая отчетность, база данных, педиатрический участок, программный комплекс, медицинские карты.
}

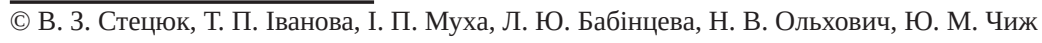


Вступ. Відомо, що рівень дитячої та малюкової смертності в світі та Україні досить високий. Однією з причин такого високого рівня є недбалий догляд за немовлятами та дітьми віком до 6 років. Після вивчення проблематики дитячої смертності та аналізу можливих шляхів зменшення її рівня виникла ідея створення комп’ютерного програмного комплексу автоматизованого ведення первинної облікової медичної документації для:

- зниження рівня дитячої та малюкової смертності;

- раннього виявлення захворювань у дітей та своєчасного направлення їх на стаціонарне лікування;

- покращення якості надання медичної допомоги дітям в умовах стаціонару вдома;

- зниження показників захворюваності дітей 1-го року життя;

- максимального охоплення та якісного проведення профілактичних медичних оглядів дітей віком до 3 років.

Мета роботи: створення комп'ютерного програмного комплексу «Медичний реєстратор» для оптимізації роботи лікаря-педіатра та медичної сестри педіатричної дільниці.

Актуальність роботи полягає в розробці дієвого інструменту у вигляді комплексу прикладних комп’ютерних програм, що забезпечує оброблення первинної облікової медичної документації на дітей педіатричних дільниць дитячої поліклініки з метою покращення якості надання медичних послуг медичними працівниками та зниження рівня дитячої та малюкової смертності.

Предметом дослідження стала локальна база даних формату Paradox та основні компоненти архітектури BDE, а об'єктом дослідження - база даних електронної медичної документації дитячої поліклініки, способи оброблення документації та отриманої інформації, формування необхідної звітності (з використанням основних елементів архітектури BDE).

Одним із завдань роботи виявилося застосування бази даних первинної облікової документації на дітей педіатричних дільниць для отримання оперативної та періодичної статистичної звітності.

Дослідження спрямовано саме на створення комп’ютерного програмного комплексу, що взяв би на себе виконання певних функцій медичного документообігу, звітності та статистики: ведення медичних електронних карток дітей від народження до 16 років, контроль за міграцією дітей в межax міста, контроль за якістю і повнотою надання медичних послуг педіатрами та медичними сестрами, контроль за дотриманням та виконанням медпрацівниками графіків обов'язкових медичних оглядів дітей віком до 3 років, формування електронної звітності та інше.

Матеріали та методи дослідження. Досліджувалась робота лікаря-педіатра, який оглядає пацієнтів і призначає лікування, проводить планові огляди, та медичної сестри, яка веде облік первинної медичної документації (відкриття нової картки новонародженої дитини, прийом та видача картки дитини, яка мігрує, тощо). Вивченню підлягав увесь процес від моменту звернення пацієнта до отримання кінцевих результатів дослідження, зокрема медичні карти, необхідні звіти та протоколи лікування, затверджені Міністерством охорони здоров’я (МО3) України [1-7].

Для розроблення представлених програмних продуктів використовували мову програмування Delphi та середовище програмування Embarcadero Delphi XE7 Builder. Для збереження даних розроблено відповідну базу даних, форматом якої обрано локальний формат Paradox, оскільки він $€$ оптимальним форматом баз даних для невеликих проектів персонального використання, написаних на Delphi. Для реалізації доступу до бази даних було обрано 32-бітний двигунець BDE.

Результати та їх обговорення. Після ретельного аналізу роботи працівників педіатричної дільниці та аналізу медичних карток було розроблено програмний продукт, що оптимізує роботу персоналу.

Програмний комплекс «Медичний реєстратор» реалізує такі функції:

• облік дітей педіатричний дільниць дитячої поліклініки від народження до 16 років за основними медичними та соціальними показниками;

- посильна допомога дільничним педіатрам при застосуванні ними протоколів лікування захворювань за діагнозами, визначеними МО3 України (за показниками повноти та своєчасності обстеження та лікування в умовах стаціонару вдома);

- облік рівня надання медичних послуг дільничними педіатрами при лікуванні в умовах стаціонару вдома;

- контроль за своєчасністю направлень дітей на стаціонарне лікування та своєчасністю їх надходження до стаціонару;

- забезпечення дільничних лікарів та медсестер графіками обов'язкових профілактичних медичних оглядів дитини у віці до 3 років; 
- контроль з боку адміністрації за дотриманням графіків обов’язкових профілактичних медичних оглядів дітей віком до 3 років та своєчасністю їх проведення;

- отримання оперативної інформації про стан захворюваності, своєчасність направлень на госпіталізацію, стан виконання дільничними лікарями та медсестрами графіків обов'язкових медичних оглядів дітей віком до 3 років;

- формування звітності за вказані періоди з можливістю перегляду та друку інформації за певними показниками.

Програмний комплекс складається 3 двох прикладних програм: «Реєстратор медичних карток» (для реєстратури педіатричної дільниці) та «Педіатрична дільниця» (для лікаря-педіатра).

Прикладна комп’ютерна програма «Реєстратор медичних карток» встановлюється на одному чи декількох комп’ютерах реєстратури дитячої поліклініки. Оператором даної програми $\epsilon$ медична сестра, яка веде облік первинної медичної документації (відкриття нової картки новонародженої дитини, прийом та видача картки дитини, яка мігрує, тощо). Ця прикладна програма не передбачає отримання медичної чи статистичної звітності.

Важливо, що користувач програми може виконувати такі дії:

- перегляд електронних медичних карток;

- друк схеми диспансерного нагляду, обстеження та лікування дітей, яких взято на диспансерний облік;
- пошук медичної картки дитини за її ПІБ (контекстний пошук), дільницею (груповий пошук), номером картки (унікальний пошук);

- фільтрація карток групи дітей за вказаними вище критеріями, за входженням дати народження до вказаного періоду, датою лікування в умовах стаціонару вдома та його результатом, датою звернення на амбулаторне лікування;

- перегляд інформації про міграцію дітей та друк відповідної відомості;

- перегляд інформації про ПІБ дільничних педіатрів;

- робота з первинною медичною документацією на дітей педіатричних дільниць дитячої поліклініки:

- відкриття / створення, додавання нової педіатричної дільниці;

- підготовка до передачі інформації про направлення дітей на госпіталізацію за поточну добу;

- підготовка до передачі медичних карток дітей, які вибули до інших дитячих поліклінік міста;

- можливість друку таких відомостей:

- інформація про дітей, які прибули на облік до даної дитячої поліклініки з інших дитячих поліклінік міста;

- інформація про дітей, які вибули до інших дитячих поліклінік міста;

- схема диспансерного нагляду, обстеження та лікування дітей, взятих на диспансерний облік.

Прикладна комп’ютерна програма «Педіатрична дільниця» (рис. 1) може бути встановлена на

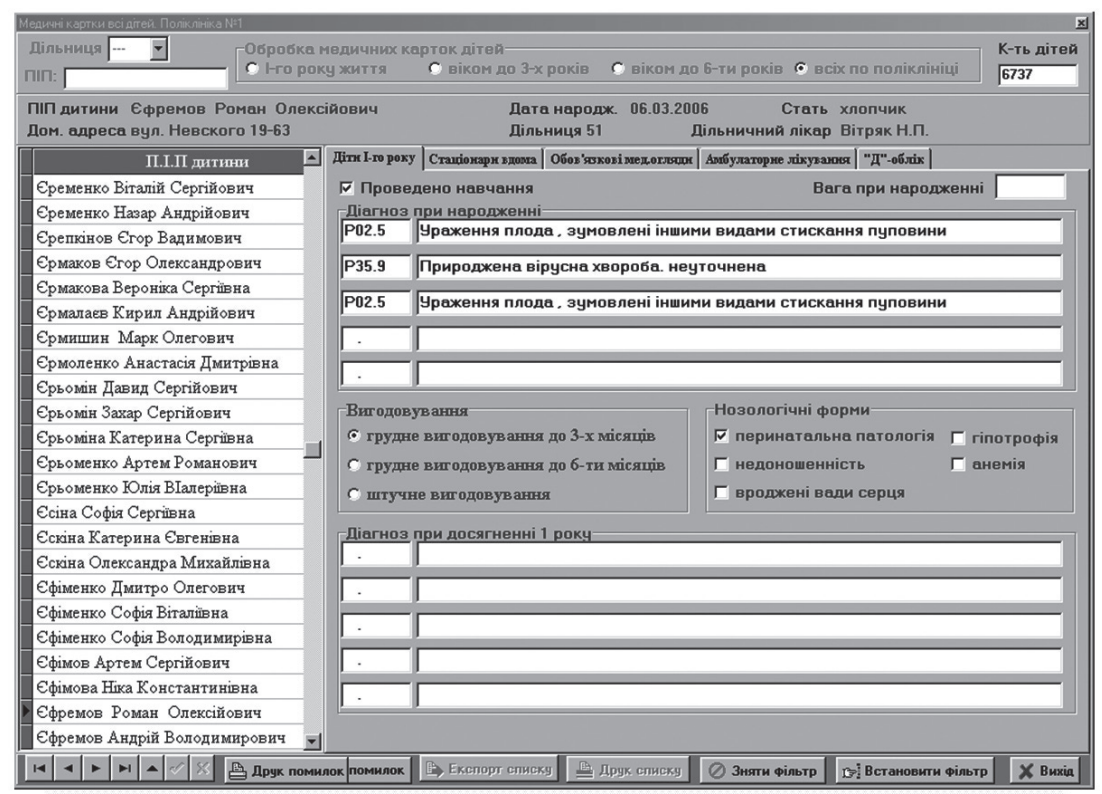

Рис. 1. Прикладна комп’ютерна програма «Педіатрична дільниця» 
будь-якому комп’ютері дільничного педіатра дитячої поліклініки. Оператором програми є дільнична медична сестра або дільничний педіатр. Дана програма може бути також встановлена і на комп’ютері завідувача дитячою поліклінікою чи його секретаря з метою контролю за виконанням протоколів та рівнем якості надання медичних послуг дільничними педіатрами при лікування дітей в умовах стаціонару вдома, дотримання ними графіків обов'язкового профілактичного медичного огляду дітей віком до 3 років.

Програма «Педіатрична дільниця» передбачає отримання повної статистичної звітності по дитячій поліклініці, оперативної та періодичної звітності рівня якості та своєчасності надання медичних послуг дільничними педіатрами та дільничними медичними сестрами.

Користувач цієї програми може виконувати такі дії:

- відбір карток дітей за віковими критеріями: діти першого року життя, діти віком до 3 чи 6 років, всі діти, які знаходяться на обліку;

- контекстний пошук за ПІБ дитини;

- груповий пошук за номером дільниці (для зручності роботи дільничного педіатра будуть відібрані тільки картки дітей даної дільниці);

- фільтрація карток групи дітей за вказаними вище критеріями, а також за входженням дати народження до вказаного періоду, датою стаціонару вдома і його результату, тощо.

- фіксація проходження навчання вагітною жінкою, маси тіла дитини при народженні, стану здоров'я дитини, якій виповнився 1 рік, стану здоров'я новонародженої дитини, видів її вигодовування, нозологічних форм захворювань;

- заповнення в електронній медичній картці дати, діагнозу дитини при її лікуванні в умовах стаціонару вдома, відмітка виконання протоколу обстежень та лікування, визначення рівня якості ії лікування в умовах стаціонару вдома;

- контроль за графіком проведення обов'язкових профілактичних медичних оглядів дітей віком до 3 років та відмітка чергового огляду;

- відмітка звернення до амбулаторного лікування до спеціаліста поліклініки із зазначенням встановленого діагнозу та періодичності подібних звернень;

- відмітка взяття на диспансерний облік із зазначенням встановленого діагнозу, друк схеми диспансерного нагляду, обстеження та лікування дітей, взятих на диспансерний облік, відмітка зняття дітей з диспансерний обліку.

Для формування звітності користувач повинен вказати вікову категорію дітей, за інформацією 3 медичної документації яких буде формуватися звітність. Звіти формуються за поточну добу, місяць, квартал чи рік. Комплект необхідних звітів визначається залежно від дати, вказаної при формуванні звітності. Звіти формуються за первинною медичною документацією на дітей 1-го року життя, віком до 3 років, віком до 6 років. Кожній віковій групі відповідають різні необхідні відомості та форми звітності.

Набір потрібних для формування звітів даних можна комбінувати.

При перегляді більшості відомостей є можливість звернення до первинної облікової медичної документації на дітей, які потрапили до сформованого звіту, тобто більшість звітів є персоніфікованими. Сформовані звіти можна переглядати та виводити до друку як в табличній формі (кількісноякісній), так і у вигляді діаграм.

Висновки. Представлений програмний комплекс спрямований на оптимізацію роботи педіатрів і персоналу педіатричної дільниці.

Результати проведеної апробації програмного комплексу вказують на високу ефективність його впровадження.

\section{Література.}

1. Міжнародна статистична класифікація хвороб та споріднених проблем охорони здоров'я / пер. 3 англ. ; ред. Н. В. Гармаш, В. М. Карпелюк. - 10-й перегляд. - Женева : Всесвітня організація охорони здоров'я, 1998. - Т. 1, Ч. 1. - 685 с.

2. Міжнародна статистична класифікація хвороб та споріднених проблем охорони здоров'я / пер. з англ. ; ред. Н. В. Гармаш, В. М. Карпелюк, В. М. Панасенко. — 10-й перегляд. - Женева : Всесвітня організація охорони здоров'я, 1998. - Т. 1, Ч. 2. — 710 c.

3. Про затвердження клінічних протоколів лікування дітей за спеціальністю «Педіатрія» : наказ МО3 України від 10.01.2005 № 9 [Електронний ресурс] / Міністерство охорони здоров'я. — Режим доступу : http://old.moz.gov.ua/ua/portal/dn_20050110_9.html.

4. Про затвердження клінічного протоколу медичного догляду за здоровою дитиною віком до 3 років : наказ МОЗ України від 20.03.2008 № 149 [Електронний ресурс] / Міністерство охорони здоров'я. Режим доступу : http://old.moz.gov.ua/ua/portal/ dn_20080320_149.html. 
5. Про затвердження Протоколу медичного догляду за здоровою новонародженою дитиною : наказ МОЗ України від 04.04.2005 № 152 [Електронний ресурс] / Нормативно-директивні документи МO3 України. - Режим доступу : http://mozdocs.kiev.ua/ view.php?id=3890.

6. Про охорону дитинства : Закон України від 26.04.2001 № 2402-III [Електронний ресурс] / Верховна Рада України. - Режим доступу: http://zakon5. rada.gov.ua/laws/show/2402-14.

7. Про удосконалення амбулаторно-поліклінічної допомоги дітям в Україні : наказ МОЗ України від 29.11.2002 № 434 [Електронний ресурс] / Нормативно-директивні документи МОЗ України. - Режим доступ у: http://mozdocs.kiev.ua/view.php?id=2016.

\section{References.}

1. Mizhnarodna statistichna klasifikatsiya khvorob ta sporidnenikh problem okhoroni zdorov'ya [International Statistical Classification of Diseases and Related Health Problems]. (1998). 10th revision. Geneva: WHO. Vol. 1, Part 1.

2. Mizhnarodna statistichna klasifikatsiya khvorob ta sporidnenikh problem okhoroni zdorov'ya [International Statistical Classification of Diseases and Related Health Problems]. (1998). 10th revision. Geneva: WHO. Vol. 1, Part 2.

3. Pro zatverdzhennya klinichnikh protokoliv likuvannya ditei za spetsial'nistyu «Pediatriya» [On the approval of clinical protocols for the treatment of children in the specialty «Pediatrics»]: decree of MH of Ukraine No. 9. (2005, January 10). Ministry of Health of Ukraine. Retrieved from: http://old.moz.gov.ua/ua/portal/ dn_20050110_9.html.
4. Pro zatverdzhennya klinichnogo protokolu medichnogo doglyadu za zdorovoyu ditinoyu vikom do 3 rokiv [On the approval of the clinical protocol of medical care for a healthy child under 3 years of age]: decree of $\mathrm{MH}$ of Ukraine No. 149. (2008, March 20). Ministry of Health of Ukraine. Retrieved from: http://old.moz.gov.ua/ua/ portal/dn_20080320_149.html.

5. Pro zatverdzhennya Protokolu medichnogo doglyadu za zdorovoyu novonarodzhenoyu ditinoyu [On the approval of the protocol for the medical care of a healthy newborn child]: decree of MH of Ukraine No. 152. (2005, April 4). Normative and directive documents of the Ministry of Health of Ukraine. Retrieved from: http://mozdocs.kiev.ua/view.php?id=3890.

6. Pro okhoronu ditinstva [On the protection of childhood]: The Law of Ukraine No. 2402-III. (2001, April 26). The Verkhovna Rada of Ukraine. Retrieved from: http:// zakon5.rada.gov.ua/laws/show/2402-14.

7. Pro udoskonalennya ambulatorno-poliklinichnoi dopomogi dityam v Ukraini [On the improvement of outpatient care for children in Ukraine]: decree of $\mathrm{MH}$ of Ukraine No. 434. (2002, November 29). Normative and directive documents of the Ministry of Health of Ukraine. Retrieved from: http://mozdocs.kiev.ua/view. php?id=2016. 